\title{
砂浜海岸帯水層における 潮位変動に伴う循環流の形成機構
}

\author{
内山雄介 ${ }^{1}$ \\ ${ }^{1}$ 正会員 博士（工）運輸省港湾技術研究所 海洋環境部漂砂研究室（干239-0826 横須賀市長瀬 3-1-1）
}

\begin{abstract}
海岸帯水層中の地下水の举動を数值モデルによって調べた. まず, 飽和-不飽和浸透流式々塩分の移流分散方程式を連 立させ, 海面の時間変動を境界条件として取り込むことにより, 海岸帯水層特有の地下密度流場を解き, かつ帯水層中に 形成される塩水楔の非定常過程を解析し得る数值モデルを示した.この数值モデルを用いて, 砂浜海岸における帯水層 中の浸透流場を解析した結果, 前浜表層において H.W.L.の汀線付近で下向き, LW.L.の汀線付近で上向きの, 局所的な

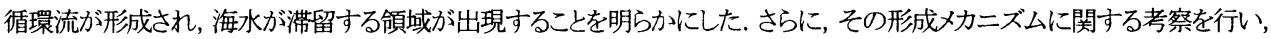
循環流が潮汐の作用によって形成されたものであること, 帯水層中の密度構造之密接に関連していること, 陸域からの淡水 フラックスの大小, 潮位振幅, 海浜勾配等によってもその形態が大きく変化することを見出した.
\end{abstract}

Key Words: coastal aquifer, sandy beach, groundwater flow, tidal circulation, numerical simulation.

\section{1.はじめに}

砂浜海岸帯水層中の地下浸透流は, 漂砂による海浜変 形過程 ${ }^{12}$,2), 海底地盤に設置された構造物の安定性 3), 内 陸部の塩水化問題 ${ }^{4}$, 海域への栄養塩供給過程 ${ }^{9}$ - , 有機 化合物の分解機構 ${ }^{8}$ ，海岸植生の生育環境 9 など，海岸 保全を含めた海岸環境全般に多大な影響を及ぼしている。 一般に背後地の地下水位は平均海水面よりも高いので， 帯水層中では陸域から海へ向かう淡水の流れが生じてい る. さらに汀線近傍では，この陸起源の淡水が海水中の 塩分と混合することによって密度の空間勾配か形成され， 結果として塩水楔が生じることが知られている.この塩 水楔に代表される汀線近傍の帯水層中の流れ場は, Fig.1 のように模式的に表されることが多い（例えば， Johannes $^{5)}$ ). 図中に示されるように, 高密度の海水は淡 水下部に潜り込むように内陸側へ浸入し, 海水面と後背 地側地下水面との水位差による淡水フラックスの大小に 応じて, 汀線部の流動構造を変化させる. 同時に, 海岸 では潮汐や波浪の遡上に伴って海水面位置が時間的, 空 間的に変化しているため, その影響を受けて, 汀線近傍 の浸透流速場もまた時空間的に変動しているものと考元 られる. また, 潮間帯周辺では, 地下水面は海水面の低 下に追従しきれずに遅れて低下するため，下げ潮時に海 水面よりも高い位置に浸潤面が形成されることが知られ ている ${ }^{10,11)}$.つまり, 汀線近傍の帯水層では, 地下水面 上の不飽和帯か時空間的に非一様に形成されることにな り，この不飽和帯の分布を精度よく見積もることが，汀 線周辺の帯水層中の物質輸送や地下水罟境を考える上で 重要なポイントの一つとなる.

汀線部の不飽和帯周辺では，潮汐や波浪の作用に伴つ
て海水が出入りしており，この領域は有機物を分解する バクテリア類にとって格好の棲息空間でもある. 他方, 後浜背後に生育する海岸植生は, 根を介して不館和帯中 の淡水や栄養篮頑を吸収している．したがって，海岸環 境という観点から地下水の挙動を考える上では, 不飽和 帯を含めた浸透流場を, 海面と地下水面の非定常性およ び帯水層中の密度分布を考慮した形で測定，あるいは解 析を行うことが強く求められる.

ところで，帯水層中の浸透流速分布を時空間的に密に 収集することは, 測定機器や測定方法の点から大幅な制 約があり, 事実上ほほ不可能である.これに対して地下 水位デー夕は極めて簡便に取得できるため, これを境界 条件として与えて，地下浸透流の支配方程式を解くこと によって内部の浸透流速分布を得ることが実際には有効 な方法となる. 浸透流の支配方程式は, 圧力ポテンシャ ルを末知量とした Darcy 則を地下水の質量保存式に代入 することによって得られるが, 用途に応じて様々な仮定 の下に方程式の簡略化が行われてきた. しかしながら， 不飽和带を含む海岸帯水層中の地下水の圧力ポテンシャ ル分布を得る際には，簡略化をほとんど行わない飽和不飽和浸透流に対する Richards 式 ${ }^{12}$ を用いる必要がある. 加えて，海岸域では塩水の浸入による密度効果を考虑す ることが本質的に重要であるため, 塩分の移流分散過程 を同時に解き，浸透流計算にフィードバックすることが 求められる.

Pinder and Cooper ${ }^{13}$ は, 定常の浸透流式と非定常の塩 分の移流分散式を連立させた数值モデルを用いて，被圧 海岸帯水層における塩水フロントの浸入挙動を調べた。 次いで Segol et al. . $^{14)}$ はこのモデルを不圧海岸帯水層へ適

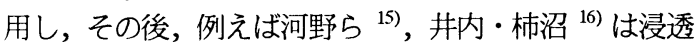




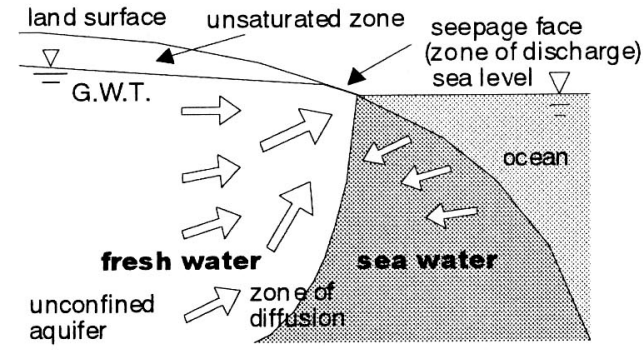

Fig. 1 Conceptual illustration of submarine groundwater discharge in an unconfined coastal aquifer (e.g., Johannes, 1980).

流式に Richards 式を用いた数值解析結果を報告している. これら既往の研究では，地表面からの水分供給や地中に おける排水等に伴う非定常流を取り扱ったケースはある ものの，潮汐や波浪の作用に伴って変動する非定常浸透 流に関して，上記の枠組を用いて解析した例は著者の知 る限りない。一方, 土屋ら ${ }^{17}$, 山元 ${ }^{18)}$, Li et al. ${ }^{199}{ }^{20)}$ は, 不圧海岸帯水層の飽和浸透流を記述する全水頭に関する Laplace 式を基礎式とした BEM（境界要素法）モデルに よって, 潮汐および波浪に伴う地下水面の非定常過程を 解析している. 特に Li et al. ${ }^{29}$ のモデルは, Parlange and Brutsaert ${ }^{21)}$ による鉛直一次元の Richards 式の近似解を境 界条件に組み込むことによって，簡単ではあるが不飽和 帯 (毛管帯) の影響を取り入れたものとなっている.し かしながら，浸透流式を Laplace 式で表現する以上，透 水係数の時空間変化を組み込めないことが根本的な問題 として残っているほか, 塩分の効果をまったく考慮して いないことも現象の正確な理解を妨げているものと考え られる.

これに対して著者のわは，Richards 式と塩分の移流分 散方程式を連立させた数值モデルに，海水面変動の効果 を境界条件として組み込むことにより，潮位変動を考慮 した海岸地下浸透流の挙動に関する検討を行っている. その結果, 潮位変動を考慮した場合には, 従来の定常解 析から得られた流速分布や塩分分布とはかなり異なった 浸透流場が形成されるとともに，現地デー夕による塩分 分布と計算結果が，より良好に一致することを示してい る.このことは, 海水面変動が密度場と流れ場の双方に 複雑に影響を及ぼして, 汀線近傍の地下水流れをダイナ ミックに変化させていることを示しており,海水面変動, 密度の非一様性を同時に考慮することの重要性を如実に 表している.

そこで本研究では, 海岸地下水の問題において極めて 重要でありながら,これまでほとんと議論されることの なかった海水面変動 (ここでは潮汐程度の周期の変動の みを刘象とする）および密度流の効果に着目し，これら
を考虑した飽和-不飽和浸透流モデルによって海岸地下 水の挙動を詳細に調べることを主たる目的とする. 具体 的には，海浜断面形状（带水層厚および前浜斜面勾配） や潮位振幅などを変化させた場合の浸透流場をシミュレ 一トし，これらの海浜性状の違いが潮間帯周辺の浸透流 場の形成に与える影響を解析すると同時に, それらのメ カニズムを考察するものである.

\section{2. 数値モデルの概要}

\section{（1）基礎方程式}

Pinder and Cooper ${ }^{13)}$, Pinder and Gray ${ }^{2)}$ と同様に, 帯水 層は均質·等方性媒体で構成されているものと考えると， 塩分の増減に伴う浸透ポテンシャルの変化を考慮した Darcy 則は以下の式（1）のように表される.

$$
\mathbf{q}=-K(\psi) \operatorname{grad}\left\{\psi+\left(\frac{\rho}{\rho_{f}}\right) z\right\}
$$

ただし, $\operatorname{grad}=(\partial / \partial x, \partial / \partial y, \partial / \partial z), x, y$ : 水平方向座 標, $z$ : 鉛直方向座標, $\mathbf{q}=\left(q_{x}, q_{y}, q_{z}\right)$ : Darcy 流速, $K$ : 透水係数, $\psi$ : 圧力ポテンシャル（不飽和帯ではマトリ ックポテンシャル), $\rho$ : 海水と淡水が混合した流体の密 度, $\rho_{f}$ : 淡水密度をそれぞれ表している。

式 (1) および間隙水の質量保存則から，地下水面と浸 透流を一体的に取り扱える Richards の飽和一不飽和浸透 流式 (2) が導かれる. 以下, 方程式の表記は総和規約に 従うものとする.

$$
\left(C_{w}(\psi)+\beta_{0} S\right) \frac{\partial \psi}{\partial t}=\frac{\partial}{\partial x_{i}}\left(K(\psi) \frac{\partial \psi}{\partial x_{i}}-\delta_{i, 3} K(\psi) \frac{\rho}{\rho_{f}}\right)
$$

ここに, $i=1,2,3, x_{i}: i$ 方向空間座標 $\left(x_{1}=x, x_{2}=y, x_{3}=\right.$ $z), \delta_{i j}$ : Kronecker のデル夕, $C_{w} \equiv \partial \theta / \partial \psi$ : 比水分容量, $t:$ 時間, $S:$ 比貯留係数, $\beta_{0}$ : 圧力ポテンシャルの変化 による空隙率の変化が生じないものと仮定した場合に次 式の值をとるダミ一変数である.

$$
\beta_{0}=\left\{\begin{array}{lll}
0 & \cdots & \text { unsaturated } \\
1 & \cdots & \text { saturated }
\end{array}\right.
$$

飽和領域および不飽和領域の両領域において, 溶質 (塩 分）に関する移流分散方程式が以下の式 (4) のように定 義される.

$$
\frac{\partial \theta C}{\partial t}+\frac{\partial}{\partial x_{i}}\left(\theta q_{i}^{\prime} C\right)=\frac{\partial}{\partial x_{i}}\left(\theta D_{i, j} \frac{\partial C}{\partial x_{j}}\right)
$$

ここに, $j=1,2,3, q_{i}^{\prime}: i$ 方向の実質流速 $\left(q_{1}^{\prime}=q_{x} / \theta_{s}, \quad q_{2}^{\prime}=\right.$ 
Table 1 Hydraulic parameters of the system being simulated.

\begin{tabular}{cccccccccc}
\hline$S$ & $K_{s}(\mathrm{~cm} / \mathrm{s})$ & $\rho_{f}\left(\mathrm{~g} / \mathrm{cm}^{3}\right)$ & $\rho_{S}\left(\mathrm{~g} / \mathrm{cm}^{3}\right)$ & $\theta_{s}$ & $\theta_{r}$ & $\lambda$ & $\alpha_{L}(\mathrm{~cm})$ & $\alpha_{T}(\mathrm{~cm})$ & $\psi_{0}\left(\mathrm{cmH}_{2} \mathrm{O}\right)$ \\
\hline \hline $1.0 \times 10^{-3}$ & $1.331 \times 10^{-2}$ & 1.0 & 1.025 & 0.3759 & $1.0 \times 10^{-3}$ & 3.0 & 2.5 & 0.5 & -100 \\
\hline
\end{tabular}

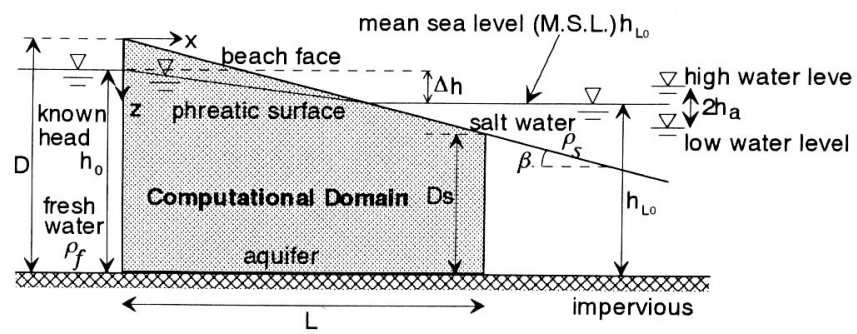

Fig.2 Schematic cross-sectional diagram of groundwater flow in an unconfined coastal aquifer used for the computations. The shaded area corresponds to the computational domain. In the diagram, $\tan \beta$ is beach slope, $D$ and $D s$ are thickness of the aquifer at the landward and seaward boundaries, $L$ is horizontal length of the computational domain, $h_{0}$ is groundwater table at the landward boundary, $h_{L 0}$ is mean sea level, $h_{a}$ is amplitude of the tidal fluctuations, and $\Delta h$ is $h_{0}-h_{L 0}$.

$q_{y} / \theta_{s}, \quad q_{3}^{\prime}=q_{z} / \theta_{s}, \theta_{s}$ : 飽和含水率 $), \theta$ : 体積含水率, $C$ : 無次元溶質濃度 (無次元塩分, 式 (6) 参照), $D_{i j}$ : 分 散係数テンソルである. また, 分散係数 $D_{i j}$ には, Scheidegger ${ }^{23}$, Bear $^{24}$ と同梯に, 流速依存型の表現式 (5) を用いることとした。

$$
\begin{aligned}
\theta D_{i, j} & =\theta\left[\begin{array}{lll}
D_{x x} & D_{x y} & D_{x z} \\
D_{y x} & D_{y y} & D_{y z} \\
D_{z x} & D_{z y} & D_{z z}
\end{array}\right] \\
& =\alpha_{T}\left|q_{i}\right| \delta_{i, j}+\left(\alpha_{L}-\alpha_{T}\right) q_{i} q_{j} /\left|q_{i}\right|+\theta v
\end{aligned}
$$

ここに, $\left|q_{\mid}\right|$: スカラー流速, $\alpha_{\mathrm{L}}$ : 横分散長, $\alpha_{T}$ : 縦分散 長, $v$ : 浸透層内の分子拡散係数であり, 式 (5) は分子 拡散の効果を内包する形で定式化されている. $\alpha_{\mathrm{L}} ， \alpha_{T}$ の 值は, 海岸域を対象とした本解析の状況に比較的近い籾 井ら ${ }^{29}$ による值 $\left(\alpha_{L}=2.5 \mathrm{~cm}, \alpha_{T}=0.5 \mathrm{~cm}\right)$ を使用した.

また, 無次元塩分 $C$ と混合流体密度 $\rho$ との間には, 以 下のような関係式がある.

$$
C=\left(\rho-\rho_{f}\right) /\left(\rho_{s}-\rho_{f}\right)
$$

ここに, $\rho_{\mathrm{s}}$ : 海水密度, である. つまり, 無次元濃度 $C$ は海水密度で 1.0 , 淡水密度で 0.0 の值をとることになる. 飽和带における透水係数の值は均質・等方性媒体では 一定であるが, 不飽和帯においては体積含水率の值によ って変化する. 本解析では, 透水係数と体積含水率との 関係を表す式として, 式（7）で示される Brooks and Corey ${ }^{29}$ の実験式を用いる.

$$
K=K_{s}\left\{\left(\theta-\theta_{r}\right) /\left(\theta_{s}-\theta_{r}\right)\right\}^{\lambda}
$$

$K_{s}$ : 飽和透水係数, $\theta_{r}$ : 最小水容量である. 飽和透水係 数および飽和含水率 $\theta_{s}$ には現地砂（茨城県鹿島灘波崎海 岸における細仯, $d_{50}=0.18 \mathrm{~mm}$ ) から求めた值, $K_{s}=1.331$ $\times 10^{-2} \mathrm{~cm} / \mathrm{s}$ および $\theta_{s}=0.3531$ を用い, 指数 $\lambda$ の值について は Irmay $^{27)}$ による理論值 $(=3.0)$ を採用し， $\theta_{r}$ は井内・杮 沼 ${ }^{16)}$ を参考に $1.0 \times 10^{-3}$ とした。 また，体積含水率とマ トリックポテンシャルとの関係式には bubbling pressure 付近の曲線に緩和部を持たせた, 谷 ${ }^{28)}$ による実験式 (8) を使用する。

$$
\left(\theta-\theta_{r}\right) /\left(\theta_{s}-\theta_{r}\right)=\left(\left|\psi / \psi_{0}\right|+1\right) \exp \left(\left|\psi / \psi_{0}\right|\right)
$$

ここで， $\psi_{0}$ : 比水分容量 $C_{w}$ の最大值を与えるマトリッ クポテンシャルである. なお, 吸水過程と排水過程では $\theta-\psi$ 関係が異なり, ヒステリシスが存在する. また, $K-\theta$ 関係においてもヒステリシスは見られるが， $\theta-\psi$ 関係に 比べて小さいことが知られている（例えば, Vachaud and Thony $\left.^{29)}\right)$. しかしながら, ヒステリシスを考虑した信頼 できるモデルが現時点では存在しないため, ここでは水 文・農業気象分野に拀い一般的に使用されている関係 式である式 (7)，（8）を用いることとした.

\section{（2）計算条件}

基礎方程式および関係式（1）〜（8）を，差分法を用 いた数值解法により解く. 空間的には 2 次精度の中央差 分を, 時間的には 1 次精度の Backward-Euler 法（完全陰 解法）を用いて離散化し, 連立方程式の解法には SOR 法を用いた. また, 各格子点上の圧力ポテンシャル, 塩 分に関する䛊差の絶刘值の総和がそれぞれ $1.0 \times 10^{2}, 1.0$ $\times 10^{4}$ に達した時点で収束したと判定した. なお, Table 1 は解析に用いたパラメータをまとめたものであり,こ 
Table 2 Numerical configuration and physical parameters for the system being simulated (Cases $1-4$ ).

\begin{tabular}{ccccccc}
\hline $\tan \beta$ & $L(\mathrm{~m})$ & $D(\mathrm{~m})$ & $D_{s}(\mathrm{~m})$ & $h_{0}(\mathrm{~m})$ & $h_{L 0}(\mathrm{~m})$ & $\Delta h(\mathrm{~m})$ \\
\hline $1 / 20$ & 100.0 & 30.0 & 25.0 & 28.5 & 27.5 & 1.0 \\
\hline & * The acronyms in the table are identified in the text and the caption of Fig. 2.
\end{tabular}

Table 3 Computational conditions for Cases 1 - 4 .

\begin{tabular}{cccc}
\hline case & density & tide & $h_{a}(\mathrm{~m})$ \\
\hline 1 & constant & not considered & 0.0 \\
2 & variable & not considered & 0.0 \\
3 & constant & considered & 1.0 \\
4 & variable & considered & 1.0 \\
\hline
\end{tabular}

れらは現地砂浜海岸（茨城県鹿島灘波崎海岸）を対象と した計算において内山ら の, Uchiyama et al. ${ }^{\text {D }}$ が使用した 值である.

数值計算では $x$ 軸を岸沖方向, $y$ 軸を沿岸方向にとり, ポテンシャルおよび塩分に関して沿岸方向に一様性を仮 定して周期境界条件を課すことにより, $x$ - $z$ 断面 2 次元の 計算を行った. ポテンシャル，塩分に関する不連続点を 含む水平および鉛直方向の境界条件については, 水平方 向に関して水面上で開放条件, 水面下では既知の無次元 塩分（淡水側で 0 , 海水側で 1.0）と静水圧分布を仮定し た既知の圧力ポテンシャルを与え，鉛直方向に関しては 通過する塩分フラックスおよび流量がゼロとした. 初期 条件は，全ポテンシャルと塩分を全領域でゼロ（静止平 衡状態，淡水）とした。

解析対象とした計算領域は Fig.2 に模式的に示す通り であり，一様勾配の砂浜海岸の一部分を模した形状を考 えた.この地形に対して, 淡水フラックス（平均地下水 位勾配), 海浜勾配, 潮位変動振幅等を変化させた計算を 行った.ここでは， $\mathrm{M}_{2}$ 分潮が卓越する海岸を想定して， 周期 12.0 時間の正弦波によって潮位変動を与えることと した（式 (9)).

$$
h_{L}=h_{L 0}+h_{a} \sin (\omega t)
$$

ここに, $h_{L 0}$ : 平均海水位 (M.S.L.), $h_{a}$ : 潮位変動振幅, $\omega$ : 振動数である. 周期 12.0 時間なので, 振動数は $\omega=2 \pi /$ $12.0(\mathrm{rad} / \mathrm{h})$ である.

計算は，まず海面の平均水位 $h_{L 0}$ を一定值として定常 塩水楔が形成されるまで（ここでは，実時間にして約 3 年間）数值積分を行い，その後，潮位変動を与えた計算 を行う,という手順で実施した（以下，簡単のため，「非 定常計算」と表記). 非定常計算を開始してから数ヶ月後 には，一潮汐間にわたって平均した塩水楔の形状が概ね 一定となり，動的な平衡状態に達した. そのため，非定 常計算では実時間で 10 ケ月間の数值積分を行った後に 計算を打ち切り，最後の一潮汐間の平均流況および塩分
分布を解析対象とした.これ以降では，計算開始から約 3 年後の流況を「定常」状態, その後潮位変動を考慮し て約 10 ケ月を経た後の最後の一潮汐にわたって平均し た流況を「動的平衡」状態と称することとする.

なお, 本数値モデルの妥当性, 海岸帯水層中の浸透流 解析に用いた場合の再現性に関しては, 別途確認済み ${ }^{30}$ である。

\section{3. 解析結果}

まず，海岸帯水層中の浸透流の基本特性を把握するた めに, 密度効果の有無, 潮位変動の有無を変えた計 4 ケ 一ス（Case 1４）の数值計算を行った. 各計算ケースに 共通の地形・潮汐などに関するパラメー夕を Table 2 に, 各ケースにおける計算条件を Table 3 亿表示する.ここ で，Case 1 と 3 では，地下水密度を一定值 $\rho_{f}$ とすること により密度流の効果を考虑しない計算を行い, Case 1 と 2 では，潮位変動振幅 $h_{a}$ を $0 \mathrm{~m}$ にすることにより潮汐の 影響を考慮しない計算を行った。

Case 1〜4 による浸透流速べクトル四および流線四を Fig.3に，また，Case 2 と 4 による無次元塩分分布を Fig.4 にそれぞれ示す．まず，潮位変動を考慮しない Case 1 と 2 の結果（Fig3 (a)，(b)）を比較すると，地下水位勾配に よって海向きの流れか駆動されており, 加えて, 汀線近 傍で湧出するような流れ場が形成されているという傾向 が両者に共通して見られる. しかしながら, 帯水層中層 から底層にかけての定常時の流況は, $x=40 \sim 60 \mathrm{~m}$ 付近 を中心に大きく異なっている.ここで, Case 1〜4ではと もに，地下水面およひ帯水層最下部は流線，海底面は等 ポテンシャル面であり，陸から海に向かう圧力勾配によ って流れが駆動されるので，全ポテンシャルは海向きか つ上向きに滅少していくことになる. その結果, 海浜表 面上の圧力ポテンシャルの不連続点である汀線部を中心 として，上向きの流れが励起される．また，Case 2 では 塩分の混入によって海底面上の圧力ポテンシャルが Case 1 よりも大きくなるため, 海底面下の帯水層中で下 向きの流れがより強く引き起こされる. さらに，この下 向き流れによって海水側から帯水層へ浸入する水塊は, 淡水よりも密度が大きいために淡水の下部に潜り込み, 陸側からの圧力勾配と界面でのせん断応力とか釣り合っ て定常状態に達し，塩水楔が形成される（Case 1，Fig.4 (a)).そのため, Case 2 (Fig.4 (b)) では地形効果と密度 

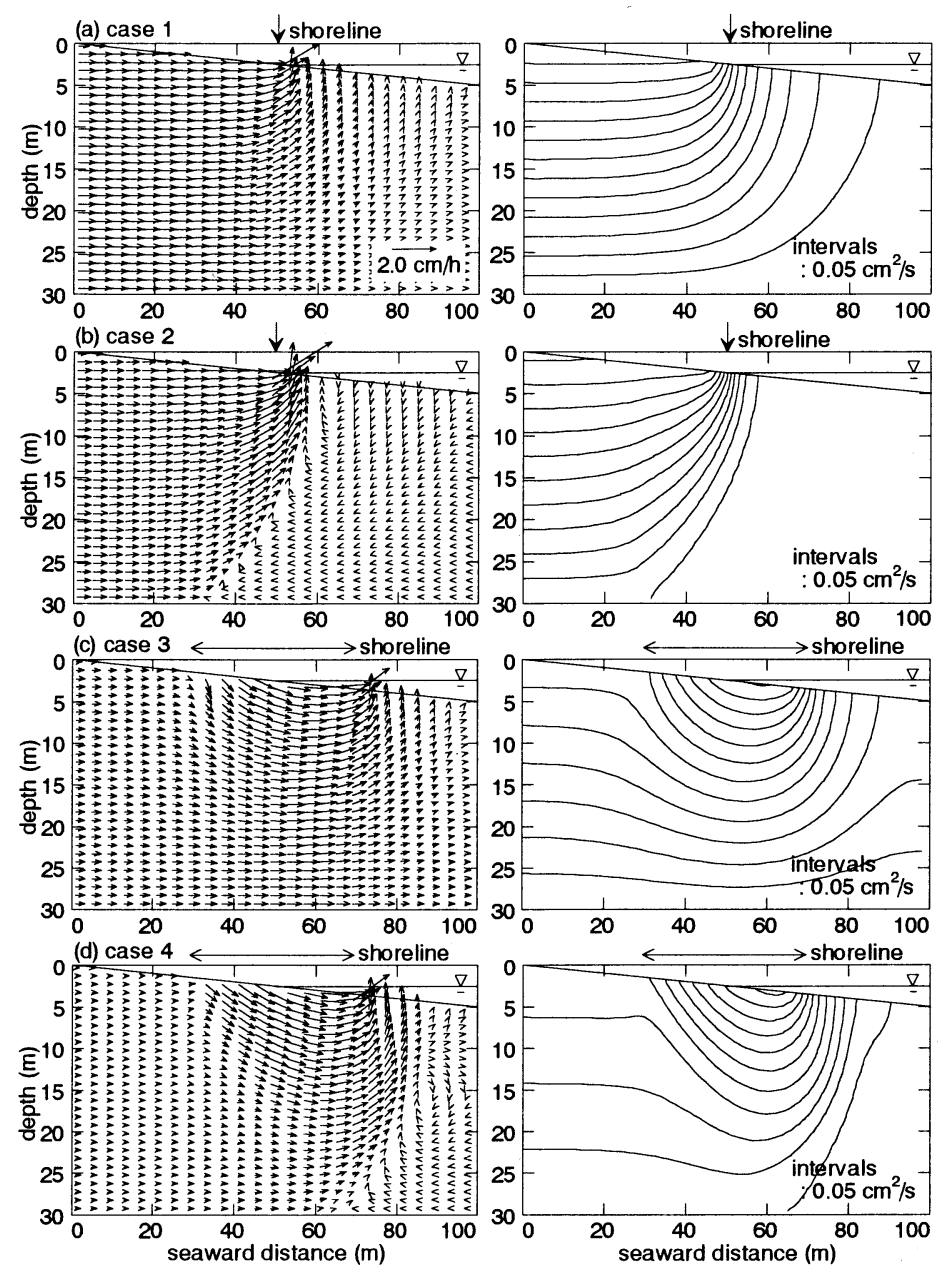

Fig.3 Velocity vectors and streamlines of the simulated flow fields for Cases $1-4$.
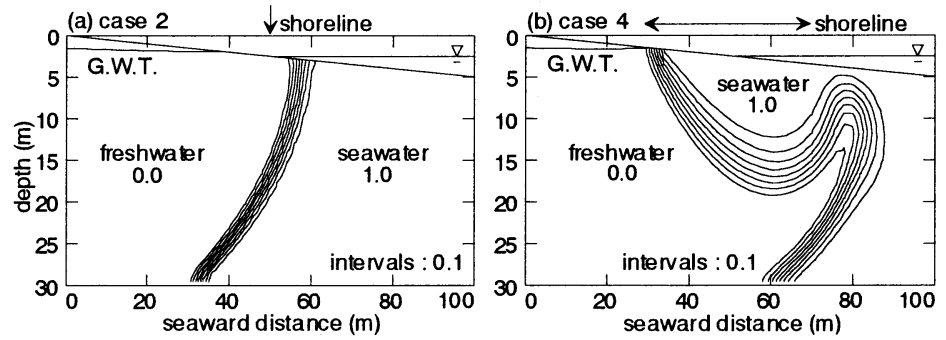

Fig.4 Simulated non-dimensional salinity distributions for (a) Case 2 and (b) Case 4 . The tidal fluctuations were incorporated in Case 4.

効果の双方の影響を受けて浸透流場が形成されることに なり, 結果として, 汀線近傍の上向き流れが助長されて いるものと解釈される.

さらに, 潮位変動を考慮した場合の流速分布 $($ Fig.3(c), (d)）を見ると，両者ともに定常状態（Fig.3 (a)，(b)）と 比較して流況がかなり変化している. 特に, 汀線近傍の
帯水層表層において鉛直方向の運動か増強され，平均的 な汀線位置 $(x=50 \mathrm{~m})$ より陸側では下向き，沖側では上 向きの，いわば局所的な「循環流」と呼ぶべき流動構造 が形成されていることが分かる.この局所循環流の水平 空間スケールは, 潮位変動に伴う汀線位置の移動範囲 $(x$ $=30 \sim 70 \mathrm{~m} ）$ に概ね対応しており，しかも密度効果の有 
Table 4 Numerical configuration and physical parameters for Cases 4-6.

\begin{tabular}{ccccccccc}
\hline Case \# & $\tan \beta$ & $L(\mathrm{~m})$ & $D(\mathrm{~m})$ & $D_{s}(\mathrm{~m})$ & $h_{0}(\mathrm{~m})$ & $h_{L 0}(\mathrm{~m})$ & $\Delta h(\mathrm{~m})$ & $h_{a}(\mathrm{~m})$ \\
\hline 4 & $1 / 20$ & 100.0 & 30.0 & 25.0 & 28.5 & 27.5 & 1.0 & 1.0 \\
5 & $1 / 20$ & 100.0 & 30.0 & 25.0 & 28.7 & 27.5 & 1.2 & 1.0 \\
6 & $1 / 20$ & 100.0 & 30.0 & 20.0 & 28.9 & 27.5 & 1.4 & 1.0 \\
\hline
\end{tabular}

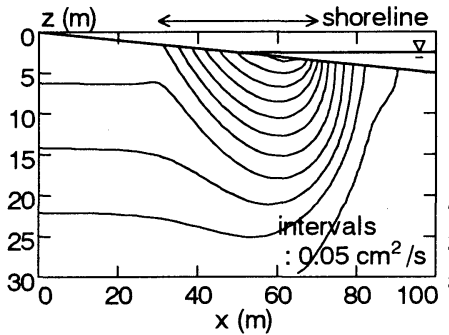

(a) Case 4

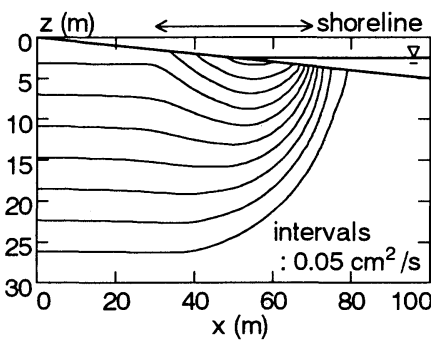

(b) Case 5

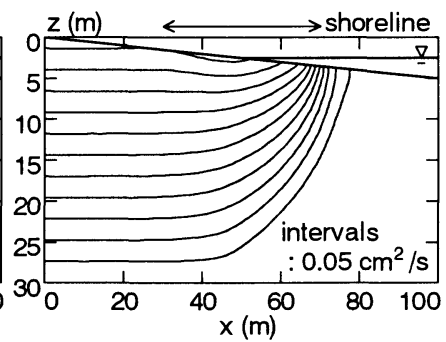

(c) Case 6

Fig.5 Streamlines calculated from the simulated groundwater flow fields for Cases 4-6.

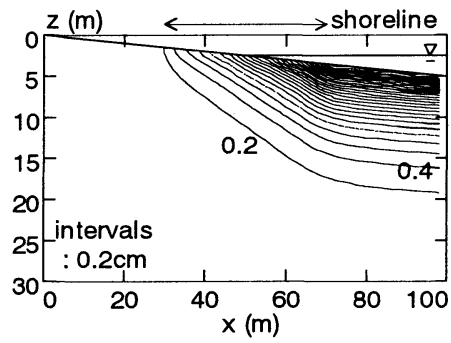

(a) $\psi_{\text {RMS. for Case } 4}$

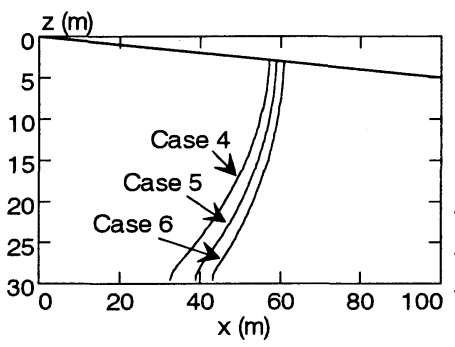

(b) interfaces for steady state

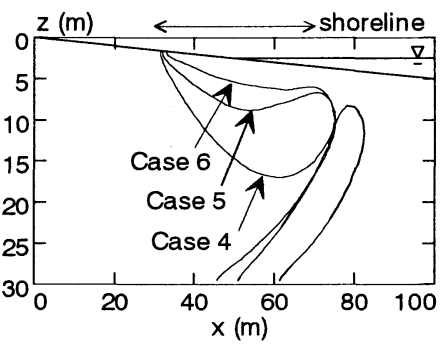

(c) interfaces for dynamic equilibrium state

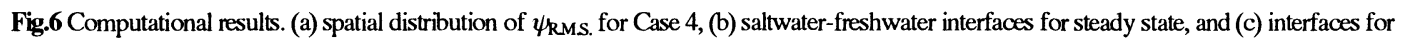
dynamic equilibrium state.

無に関わらず生じることから, 循環流は潮位変動の影響 によって生じたものであることが分かる.

また, Fig4に示されているように, 塩水混入を考虑し たCase 2 と 4 による塩分分布も,定常時(Case 2,Fig.4(b)) と動的平衡時（Case 4, Fig.4 (d)) とでは大きく異なって おり，潮汐を考慮することにより，塩水楔の位置が全体 的に海側へ移動するとともに, 循環流が生じている帯水 層表層部では，内陸側入屈曲して傾いたような形で塩分 の濃い領域が侵入している.

この循環流の形成メカニズムは以下のようであると 考えられる. まず, 潮間帯下の帯水層表層では, 上げ潮 時に海水が供給されて下方へ浸透し，下げ潮時には海側 へ流出する. 動的平衡時には, 海浜表面上の圧力ポテン シャルの不連続点である汀線が潮汐に伴って移動するこ とになるため, 定常時に $x=50 \sim 60 \mathrm{~m}$ の位置にあった沼 出点は, 常に冠水している地点である干潮時汀線 $(x=$ $70 \mathrm{~m}$ ）付近に向かって沖側へ移動する. その結果, 潮間 帯陸側では下方へ向かい，海側では上方へ向かう流れが
支配的になり，一潮汐平均した時に局所的な循環流パタ ーンが形成されたものと考察される.

さらに, Fig.4 から, 動的平衡状態 (Case 4) では定常 状態（Case 2) よりも淡塩境界の分散幅が広くなってお り,境界面が相対的に不鮮明になっていることが分かる. これは，潮位変動によって生じた非定常流れによって淡 水と塩水がより強く混合したことを示しており，その結 果, 平均的な海陸間の圧力勾配が同一であるにも関わら ず, 淡水流量が減少した (Fig.3 (b), (d)) ものと推察され る. 以上のことから，潮汐およひ塩分混入の影響を受け て, 帯水層内部の物質輸送プロセスは両者を考慮しない 状態から大きく変化することが示された.

\section{4. 考察}

\section{（1）循環流に及ぼす淡水フラックスの影響}

以下では，海岸帯水層中に出現する循環流が，様々な 外的要因によって，その構造をどのように変化させるか 
Table 5 Numerical configuration and physical parameters for Cases 7 - 9 .

\begin{tabular}{ccccccccc}
\hline Case \# & $\tan \beta$ & $L(\mathrm{~m})$ & $D(\mathrm{~m})$ & $D_{s}(\mathrm{~m})$ & $h_{0}(\mathrm{~m})$ & $h_{L 0}(\mathrm{~m})$ & $\Delta h(\mathrm{~m})$ & $h_{a}(\mathrm{~m})$ \\
\hline 7 & $1 / 20$ & 100.0 & 15.0 & 10.0 & 28.5 & 27.5 & 1.0 & 1.0 \\
8 & $1 / 20$ & 100.0 & 15.0 & 10.0 & 28.7 & 27.5 & 1.2 & 1.0 \\
9 & $1 / 20$ & 100.0 & 15.0 & 10.0 & 28.9 & 27.5 & 1.4 & 1.0 \\
\hline
\end{tabular}

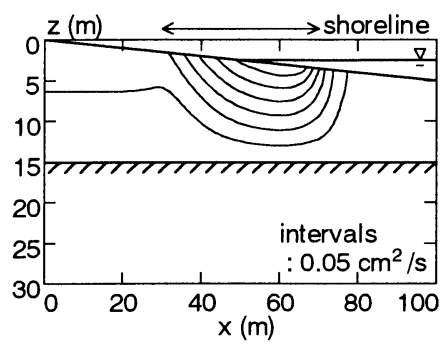

(a) Case 7

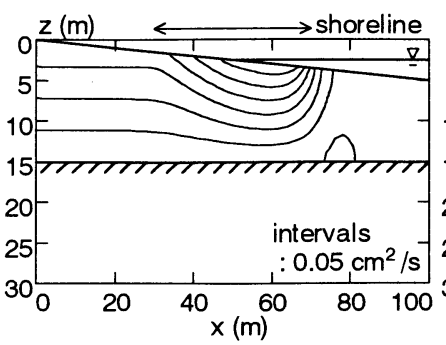

(b) Case 8

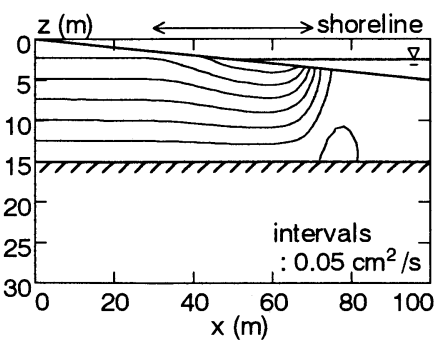

(c) Case 9

Fig.7 Streamlines calculated from the simulated groundwater flow fields for Cases 7-9.

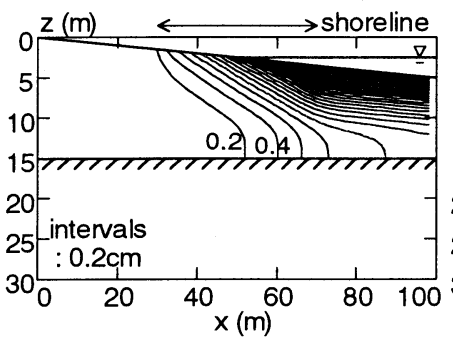

(a) $\psi_{\text {R.M. }}$ for Case 7

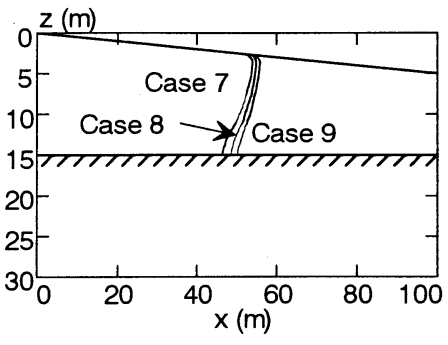

(b) interfaces for steady state

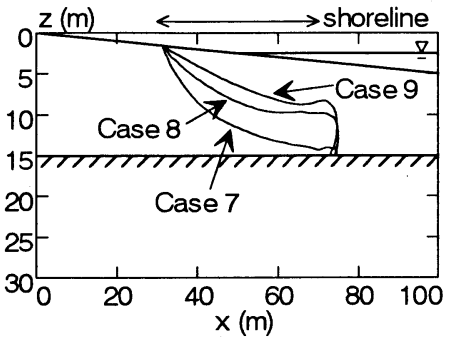

(c) interfaces for dynamic equilibrium state

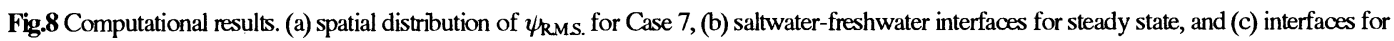
dynamic equilibrium state.

を調べる. 本節では, 陸域からの淡水フラックスの大小 がこれらの構造に及ぼす影響について，Case 4〜6 の 3 通りの計算を行い,それらを比較する形で検討する.Case 4 6 の計算条件等を Table 4 に示す. 淡水フラックスは 平均地下水面勾配によって変化させており,ヘッド差 $\Delta h$ $=1.0 \mathrm{~m}$ とした Case 4 ほど淡水流量が少なく, Case 5, 6 の順に多くなっている.

Fig5 (a)〜(c) は，それぞれ Case 4〜6による動的平衡 状態における平均流速場から求めた流線を表している. 内陸からの淡水流量が最も少ない Case 4 では, 潮間帯周 辺の帯水層表層において, 最高潮時汀線側では下方へ, 最低潮時汀線側では上方へ向かう循環流が形成されてい る. さらに，その構造は Case 5,6 と比較してかなり明 確であり, $\Delta h$ の増加とともに明確さを失っていく傾向 にあることが分かる. 淡水フラックスの増加は, 海向き 浸透流を助長するとともに，淡塩境界によって上方へ流 向を変えられて汀線周辺で湧出するというパ夕ーンを強 化することになる．そのため，淡水フラックスが多いほ
ど潮汐の影響が相対的に小さくなり，定常状態の流れ場

（Fig3 (b)）としての性質が浸透流場に強く現れて，循 環流構造が相対的に不明瞭になったものと解釈される.

また，浸透流場に対する潮位変動の効果を見るため，

Case 4 で求めた圧力ポテンシャル $\psi$ について一潮汐間の

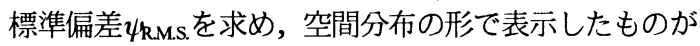

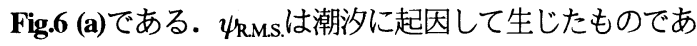
るが, その值は内陸側ほど小さく, 帯水層表層ほど大き く, しかも海浜表面下 13〜15m 程度よりも下層ではほぼ ゼロである. なお,ここでは示さないが, Case 5, 6 にお

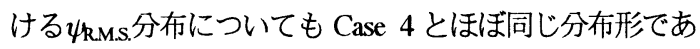
つた. つまり, Case 4〜6では, 外力（潮汐）条件が同一 であるため, 潮汐による循環流の強さには殆ど差が生じ ず, 淡水フラックスの増加によって海向きの流れか強く なり,循環流構造が見えにくくなったものと考察される.

次に, Case 4〜6における定常 (すなわち, 非定常計算 を行う直前）および動的平衡時の淡塩境界形状を Fig.6 (a)，(b)に示す. ただし，ここでは淡塩境界として，無次 


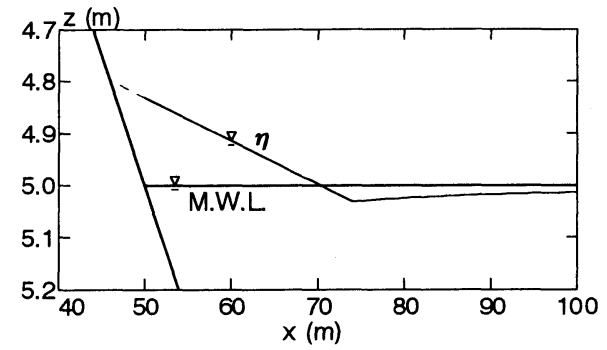

Fig. 9 Cross-shore profile of the mean sea level $\eta$ affected by wave set-up and set-down used for Case $10-12$.

元塩分 $C=0.5$ の等值線を用いている(以下同様).図から, 淡水流量の増大に伴って, 定常塩水楔は全体的な位置を 沖側へ，動的平衡状態では帯水層表層に滞留した塩水塊 を上方へと徐々に押し上げられている様子が見て取れる。 これらは, 淡水フラックスの増加によって帯水層内部の 力学バランスが変化した結果生じたものであり, 特に動 的平衡状態では, 流量の増加に伴って循環流パターンが 不明確になることに対応して，塩分の滞留域か縮小され ていることが分かる.

\section{（2）循環流に及ぼす帯水層厚さの影響}

帯水層の性質は，それを構成する土粒子の構造によっ て決定されているが，地表面からより近い位置に粘土な どの不透水性, 若しくは難透水性の地盤が存在する場合 には，帯水層の厚さが相対的に薄くなる. 通常, この帯 水層厚 $D$ は, 海岸あるいは場所ごとに異なるので, 海岸 地下浸透流，あるいは循環流に及ぼす帯水層厚の影響を 検討しておく必要がある. そこでここでは, $D=15.0 \mathrm{~m}$ とした解析を行い, $D=30.0 \mathrm{~m}$ を与えた Case 4 6 の結果 と比較する. つまり, 潮位変動や海浜勾配は Case 4 6 と同じ値を用い, 水位差 $\Delta h$ を $1.0 \mathrm{~m}$ から $1.4 \mathrm{~m}$ まで変化 させた Case 7〜9 の 3 通りの計算を実施した（Table 5).

Case 7〜9における流線パターンを見ると（Fig.7），潮 間帯表層に形成される局所循環流は Case 4〜9（Fig.5) と同程度の空間規模であるものの, 下層部では不透水層 によって循環流が十分に発達していないことが分かる.

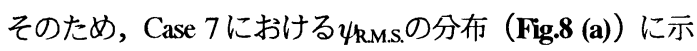
されているように，潮汐の影響範囲が不透水層にまで到 達している.このことは, 砂層の厚さがあまり大きくな い海岸では, 潮汐による圧力ポテンシャル変化の影響が 前浜から沖側の帯水層全体に現れ，結果として不透水地 盤によって局所循環流の発達が阻害される可能性がある ことを示唆している.

続いて, 定常および動的平衡状態における, Case 7〜9 による淡塩境界形状をそれぞれ Fig.8 (b)，(c) に示す. 境 界の定義は $C=0.5$ である. 定常状態では, 淡水フラック スが大きいほど淡塩境界が海側に出現しており, 帯水層
厚さ $D=30.0 \mathrm{~m}$ の場合（Case 4 6）と傾向は同じである ことが分かる. 潮汐を考慮した動的平衡状態では（Fig.8 (c)), 表層部分は Case 4〜6（Fig.6 (b)，(c)）と良く似た 形状をしているが，最低潮時汀線直下付近に見られるよ うな, 淡水が上方へ差し込むという傾向か若干弱くなっ ている.これは, Case 7〜9では不透水層の影響によって 循環流の発達が弱められたことに起因しており, 湧出点 へ向かう上昇流の流速が低隇したため, 淡水の差し込み が見えにくくなったものと思われる. すなわち, 帯水層 厚が小さい場合には，不透水層に阻害されるため循環流 が相対的に弱くなり，上昇流に伴う淡水の差し込みが弱 まった結果, Case 4〜 6に見られたような塩分分布の空間 的な非一様性が失われたものと解釉される.

\section{（3）循環流に及ぼす wave set-up, set-down の影響}

実海浜では波浪の来襲に伴って，砕波点に至るまでは wave set-down が，それより陸側においては wave set-up が生じ, 平均海水位の空間的な非一様性によって海底面 (あるいは帯水層表層) に圧力勾配が形成され，浸透流 場に影響を及ぼす。 wave set-upによって起こる砕波帯下 の浸透流場については，すでに Longuet-Higgins ${ }^{31}$ が一様 密度, 一定勾配の海浜における定常理論解を求め, 汀線 部から帯水層へ海水が浸入し，砕波点において上向きに 湧出するような流れ場 (percolation) が形成されることを 示している. また, 土屋ら ${ }^{17)}$, 山元 ${ }^{18}$, は, 波浪伝播計 算および海浜流計算と, 一様密度場における浸透流計算 とを組み合わせた非定常解析を行い, 背後地からの淡水 フラックスが大きい場合には Longuet-Higgins ${ }^{31)}$ が示し た set-up, set-downによって生じる浸透流の特性が失わ れるという結果を得ている. 一方, 井内・杮沼 ${ }^{19}$ は, 密 度を考慮した定常浸透流計算にシンプルな set-up, set-down 量分布を与えて, 定性的には Longuet-Higgins ${ }^{31)}$ と同様の浸透流場が形成されるという結果を得ている. ここでは, 井内・杮沼 ${ }^{19}$ にならい, 本モデルに単純な set-up, set-down 分布を与え, さらに密度を考慮した非定 常計算を行うことにより, set-up と set-down が浸透流場 に及ぼす影響について検討する。

波浪による wave set-up 量, set-down 量 $\eta$ は, それぞれ 式（10）及び（11）により算定する ${ }^{16)}$.

$$
\begin{aligned}
& \eta=K_{w}\left(h_{b}-h_{w}\right)+\eta_{b} \\
& \eta=-\frac{1}{16} \frac{H_{w 0}{ }^{2} k_{0} \operatorname{coth}^{2} k h_{w}}{k h_{w}+\sinh k h_{w} \cosh k h_{w}}
\end{aligned}
$$

ここに, $K_{w}=1 /\left(1+8 /\left(3 \gamma^{2}\right)\right), \gamma=0.73, H_{n 0}$ : 沖波波高, $k$ : 波数, $h_{w}$ : 水深, $\eta_{b}$ : 研波点における set-down 量であり, 
Table 6 Numerical configuration and physical parameters for Cases $10-12$.

\begin{tabular}{ccccccccc}
\hline Case \# & $\tan \beta$ & $L(\mathrm{~m})$ & $D(\mathrm{~m})$ & $D_{s}(\mathrm{~m})$ & $h_{0}(\mathrm{~m})$ & $h_{L 0}(\mathrm{~m})$ & $\Delta h(\mathrm{~m})$ & $h_{a}(\mathrm{~m})$ \\
\hline 10 & $1 / 20$ & 100.0 & 30.0 & 25.0 & 28.5 & 27.5 & 1.0 & 1.0 \\
11 & $1 / 20$ & 100.0 & 30.0 & 25.0 & 28.7 & 27.5 & 1.2 & 1.0 \\
12 & $1 / 20$ & 100.0 & 30.0 & 20.0 & 28.9 & 27.5 & 1.4 & 1.0 \\
\hline
\end{tabular}

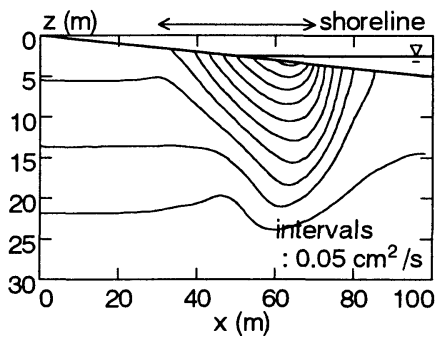

(a) Case 10

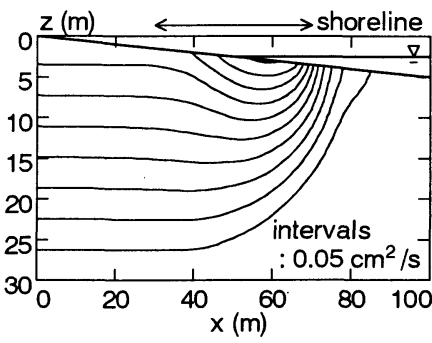

(b) Case 11

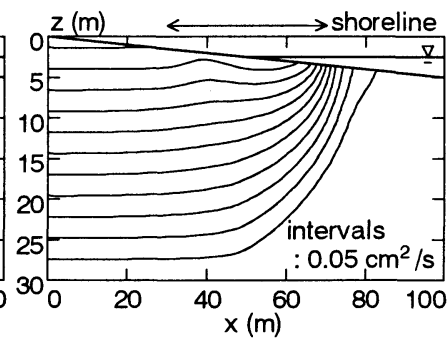

(c) Case 12

Fig.10 Streamlines calculated from the simulated groundwater flow fields for Cases $10-12$.

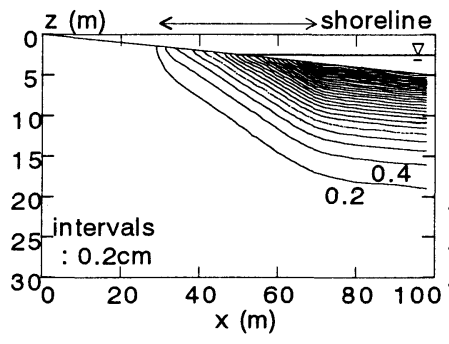

(a) $\psi_{\text {RMs. for Case } 10}$

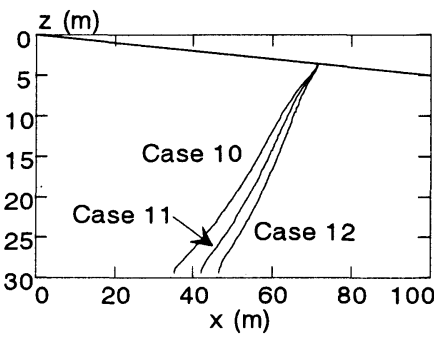

(b) interfaces for steady state

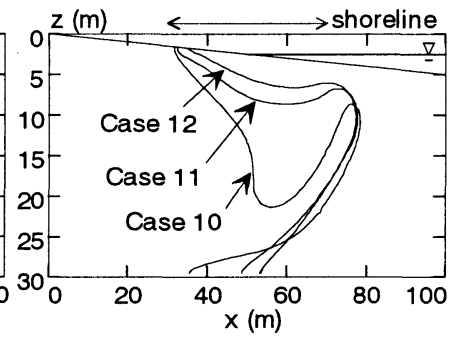

(c) interfaces for dynamic equilibrium state

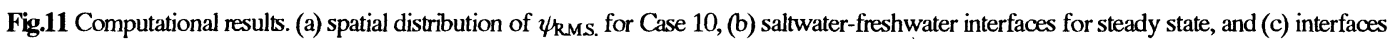
for dynamic equilibrium state.

添え字 $b$ と0ははれれそれ砕波点および沖波を表す．砕波 点は波高水深比が 0.8 に達した地点とした. なお，海岸 帯水層では波浪の作用に伴う radiation stress によって, 海 底面から運動量が伝えられて浸透流場に影響を及ぼす可 能性もある（例えば透水層を埋設した海岸帯水層中の流 れに関する片山ら ${ }^{32)}$ の議論). しかし,ここでは簡単に, 上式によって計算される set-up, set-down 量 $\eta$ の効果は, 水深に $\eta$ を加えた静水圧のみが海底地盤に作用すると考 えて, 海底面の境界条件に組み込んだ.

Fig.9 は，上記の方法によって算定された wave set-up と set-down 量の岸沖分布であり, 沖波波高 $1.0 \mathrm{~m}$, 沖波周 期 $5.0 \mathrm{~s}$ を与えて計算したものである.汀線における set-up 量は $16.9 \mathrm{~cm}$, 砕波点における set-down 量は $3.1 \mathrm{~cm}$ である. 平均海水面は, この分布形を保ちながら, 潮汐に伴う水 深変化によって時空間的に変動するため, その効果を考 慮した形で数值モデルに取り込んだ.ここでは, wave set-up と set-down 量を考慮すること以外は，地形や潮汐 などすべての条件を Case 4 6 と同一にした 3 通りの計
算（Case 10〜12）を行った. 計算条件等は Table 6に示 す通りであり, set-up, set-down を考慮する以外は Case 4 ６（Table 4）と全く同一の条件である.

動的平衡状態における流況を見ると（Fig.10), set-up を考慮しない Case 4 6（Fig5）と比較して, 全体的に は概ね同様な流線パターンとなっているが, Case 10〜12 では，帯水層中の流線がわずかに上向きに押し上げられ ているような傾向が見られる. これは, set-up, set-down による海面勾配に対応した海底面上の圧力勾配によって， 砕波点に向かって鉛直上向き流れが带水層中に生じた結 果を反映しているものと思われる. また, Case 10 におけ る $\psi_{\text {k.M.S. }}$ (Fig.11 (a)) は, Case 4 における $\psi_{\text {R.M. }}$ (Fig.6 (a)) とほぼ同様の分布形状をしていることから, set-up, set-down の影響は，潮汐による海底面上での圧力変動そ のものと比較して小さく,帯水層内部の $\psi_{\text {R.M. } . \text { 変化には明 }}$ 確には現れないことが分かる。

定常淡塩境界形状（Fig.11 (b)）は, set-up を考虑して いない Case 4〜6（Fig.6 (b)）と比較して, 淡水フラック 
Table 7 Numerical configuration and physical parameters for Cases 4, 13, and 14.

\begin{tabular}{ccccccccc}
\hline Case \# & $\tan \beta$ & $L(\mathrm{~m})$ & $D(\mathrm{~m})$ & $D_{s}(\mathrm{~m})$ & $h_{0}(\mathrm{~m})$ & $h_{L 0}(\mathrm{~m})$ & $\Delta h(\mathrm{~m})$ & $h_{a}(\mathrm{~m})$ \\
\hline 4 & $1 / 20$ & 100.0 & 30.0 & 25.0 & 28.5 & 27.5 & 1.0 & 1.0 \\
13 & $1 / 20$ & 100.0 & 30.0 & 25.0 & 28.5 & 27.5 & 1.0 & 0.5 \\
14 & $1 / 10$ & 100.0 & 30.0 & 20.0 & 26.0 & 25.0 & 1.0 & 1.0 \\
\hline
\end{tabular}

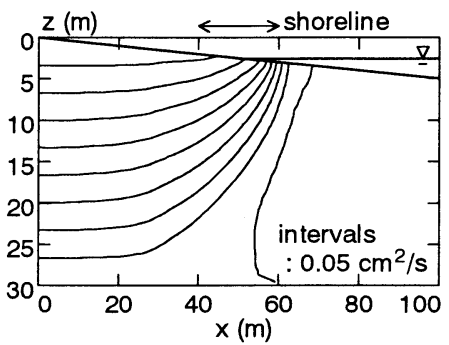

(a) streamlines for Case 13

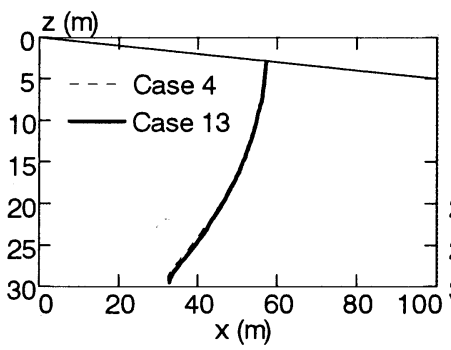

(b) interfaces for steady state

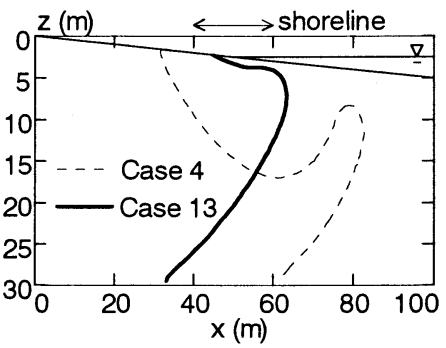

(c) interfaces for dynamic equilibrium state

Fig.12 Computational results for Case 13. (a) streamlines, (b) saltwater-freshwater interfaces for steady state, and (c) interfaces for dynamic equilibrium state. The interfaces estimated by Case 4 are superposed on (b) and (c), represented by dotted lines.

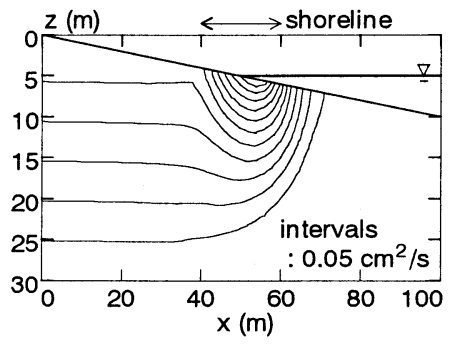

(a) streamlines for Case 14

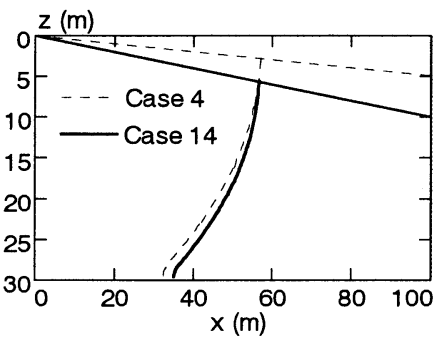

(b) interfaces for steady state

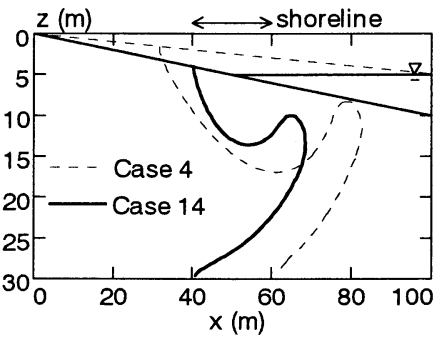

(c) interfaces for dynamic equilibrium state

Fig.13 Computational results for Case 14. (a) streamlines, (b) saltwater-freshwater interfaces for steady state, and (c) interfaces for dynamic equilibrium state. The interfaces estimated by Case 4 are superposed on (b) and (c), represented by dotted lines.

スが多いほど海側にシフトする傾向は同じであるものの， set-up を考慮した場合には, 帯水層表層で一点に収敛す る形になっている.この点は, 平均的な砕波点すなわち set-down 量が最大となる点に対応しており，海底面に形 成される圧力勾配によって, 流れの湧出ポイントが Case 4〜6よりも沖側へずれたことを示している. 動的平衡状 態の淡塩境界形状（Fig.11 (c)）は, Case 4〜6（Fig.6(c)） と比較して，Fig.10 に示した流線パターンにも見られた ように, set-up, set-downに起因した上昇流によって, 若 干，上向きかつ海向きに押し上げられたような分布とな つてはいるものの，全体的な形状は Case 4〜6 と概小同 じである. すなわち, 山元 ${ }^{18)}$ による密度を考慮しない解 析結果と同様に，海面の非定常変動に加えて密度を考慮 した場合についても，浸透流場と循環流構造に対する wave set-up, wave set-down の影響はそれほど大きくない ものと結論付けられる。

\section{（4）循環流に及ぼす海底勾配, 潮位変動振幅の影響}

循環流に影響を与える外的要因として，ここでは，潮 位変動振幅と海浜勾配の変化を取り上げる. 各計算は, Table 7 に示すように, Case 4 と比較する形で行われてお り, (a)Case 13: 潮位変動振幅を Case 4 の半分 $\left(h_{a}=0.5 \mathrm{~m}\right)$ にしたケース，(b)Case 14: 海浜勾配を Case 4 の 2 倍(す なわち, $\tan \beta=1 / 10)$ にしたケースである.

まず,Case 13 による動的平衡時の流況を見ると(Fig.12 (a)), Case 4 (Fig5 (a)) と比較して, 潮間帯周辺におけ る循環流構造がかなり不明暸となっている.このことは, 潮位変動振幅が小さい場合には，潮位変動によって汀線 部に生じる循環流は空間規模が縮小されて，その構造が 不明瞭になることを示している. Fig.12 (b)，(c) は，そ れぞれ定常状態および動的平衡状態における Case 13 に よる淡塩境界形状 $(C=0.5)$ を Case 4 と比較する形で示 したものである. Case 4 と 14 とでは, 当然ながら定常境 界形状は一致するが, 動的平衡時には大きな差異が見ら 
れ, 潮位変動振幅 $h_{a}$ を半分にしただけで循環流の空間規 模が著しく小さくなっていることが再確認される.

また, Case 14 における流線パターン (Fig.13 (a)) から は, Case 4 (Fig5 (a)) よりも循環流の空間スケールは小 さいものの，流線間隔が狭く，したがってより強い流れ が汀線近傍に生じていることが分かる.これは，海浜勾 配が大きいほど潮汐に伴うポテンシャルの鉛直勾配の変 化が大きくなって鉛直流速変動が強化された結果, 循環 流が強められたことを表しているものと考察される. た だし，循環流の空間スケールは潮汐による汀線の変動範 囲とほぼ対応するため, 同じ潮位変動振幅に対してより 急勾配の海底地形を与えた Case 14 の方が汀線の移動範 囲が狭くなり，Case 4 よりも小規模になっている．淡塩 境界（Fig.13 (b)，(c)）を見ても，定常時の形状は概小一 致しているものの，潮汐を考慮した場合には循環流の空 間規模がかなり小さくなっていることが分かる.

\section{5. おわりに}

本研究では, 海水面変動, 密度効果, 不飽和帯の浸透 流を統一的に解析し得る数值モデルを用いて，海岸帯水 層中の地下水の挙動を詳細に調べた. その結果, 潮汐程 度の周期を有する海面変動を考慮することによって，汀 線周辺の帯水層中に「局所的な循環流」と呼ぶべき特徵 的な流れが形成されることを見出した. 同時に，その影 響を受けて地下塩水楔が内陸側に屈曲したような分布に 変化し, 帯水層表層に塩分が滞留する領域が出現するこ とが明らかになった. また，陸域からの淡水フラックス が大きいほど汀線近傍に生じる上昇流が卓越し，循環流 構造が不明瞭になることを示した.さらに, 潮位変動振 幅が小さい場合には循環流が弱められること，海浜勾配 が急峻な場合には循環流速が強化されること, wave set-up および set-down は循環流の発達に対して海面変動 ほどは寄与しないことなどを明らかにした。

本研究で示されたように,海岸帯水層中に形成される, 汀線近傍の循環流構造は, 砂浜海岸における海底面直下 の浸透流場を著しく変形させている. 前浜から後浜にか けての帯水層表層における地下浸透流は，海浜変形に対 して重要な役割を果たしているため，今後はこのような 循環流の寄与を考虑しながら底質移動のダイナミクスを 検討していくことが必要となろう.さらに, 循環流に伴 う塩分場の変化は, 前浜部の生化学環境を大きく変化さ せる可能性がある，例えば，硝化細菌活性の塩分依存性 は広く知られるところであり ${ }^{8)}$, 帯水層における砂浜の 浄化機能や，背後地から海域への栄養塩輸送過程を考え る際には，前浜部分の塩分環境を詳細に把握しておく必 要がある.このように, 汀線近傍に発達する循環流は海 岸環境全般に少なからずインパクトを与え得るものであ
り,その重要性は極めて大きい.

謝辞：本研究の遂行にあたり, 東京工業大学・灘岡和夫 教授, Queensland 大学・Peter Nielsen 助教授には, 内陸力 らの淡水流量および潮位変動と淡塩境界形状の関係を中 心に，数々の貴重なご意見を頂いた．また，本論文で用 いた数值モデルは，灘岡教授のご指導のもとに作成した コードのクをべースにしたものである.ここに記して深 甚なる感謝の意を表します。

\section{参考文献}

1) Duncan, J.R. : The effects of watertable and tide cycle on swash-backwash sediment distribution and beach profile development, Mar. Geol., Vol.2, pp.186-197, 1964.

2) 加藤一正, 柳嶋慎一:長周期波によるバームの侵食, 土木学 会論文集, No.452/II-20, pp.41-50, 1992.

3）善 功企, 山嵭浩之, 森川嘉之, 小池二三勝:サクション基礎 沈設時の必要排水量に関する考察，港湾技研報告, Vol.37, No.4, pp.135-148, 1998.

4) 村下敏夫:本邦における地下水の塩水化, 地調月報, Vol.33, No.10, pp.479-530, 1982.

5) Johannes, R.E. The ecological significance of the submarine discharge of groundwater, Mar. Ecol. Prog. Ser., Vol3, pp.365-373, 1980.

6) 内山雄介, Rölke, P., 足立久美子, 灘岡和夫, 八木 宏: 海岸 地下浸透流およびそれに伴う沿岸域への栄養塩輸送過程, 土木学会論文集, No.635/II-49, pp.127-139, 1999.

7) Uchiyama, Y., Nadaoka, K., Rölke, P., Adachi, K. and Yagi, H.: Submarine groundwater discharge into the sea and associated nutrient transport in a sandy beach, Water Resour. Res., Vol. 36, No.6, pp.1467-1479, 2000.

8) 坂本市太郎: 砂浜の潮汐に伴亏呼吸 (有機物の好気分解代謝) 機能, 用水之廃水, Vol.36, No.1, pp.44-52, 1994.

9) 灘岡和夫, 内山雄介, 東川孝治:大気および土㙵中の塩分か らみた砂浜海岸植生環境について, 海岸工学論文集, 第 43 巻, pp.1171-1175, 1996.

10) Nielsen, P.:Tidal dynamics of the water table in beaches, Water Resour. Res., Vol. 26, pp.2127-2134, 1990.

11) Turner, I.:Water table outcropping on macro-tidal beaches: A simulation model, Mar. Geol., Vol. 115, pp.227-238, 1993.

12) Richards, LA., Capillary conduction of liquids through porous mediums, Physics, Vol. 1, pp.318-333, 1931.

13) Pinder, G. F. and Cooper, Jr. H. H.:A numerical technique for calculating the transient position of the saltwater front, Water Resour. Res., Vol.6, No.3, pp.875-882, 1970.

14) Segol, G., Pinder, GF. and Gray, W.G.:A Galerkin finite element technique for calculating the transient position of the saltwater front, Water Resour. Res., Vol.11, pp.353-347, 1975.

15) 河野伊一郎, 西垣 誠, 田中慎一:飽和·不飽和浸透流におけ る非定常塩水化現象の有限要素法解析, 土木学会論文報告 集, No.331,pp.133-141, 1983.

16) 井内国光, 杮沼忠男:海岸における自由地下水の流出, 海岸 工学論文集, 第 43 巻, pp.541-545, 1996.

17) 土屋義人, 山元淳史, 山下隆男, 赤村重紀:砂浜海岸におけ る海岸地下水の挙動, 海岸工学論文集, 第 40 巻, pp.571-575, 1993.

18）山元淳史:海岸地下水の理論々砂浜海岸および沿岸埋立地へ 
の応用に関する研究, 京都大学学位論文, 151p, 1993.

19) Li, L., Barry, D.A., Parlange, J.Y. and Pattiaratchi, C.B.:Beach water table fluctuations due to wave run-up: Capillary effects, Water Resour. Res., Vol.33, pp. 935-945, 1997.

20) Li, L., Barry, D.A and Pattiaratchi, C.B., Numerical modeling of tide-induced beach water table fluctuations, Coastal Eng., Vol.30, pp.105-123, 1997.

21) Parlange, J.Y., and Brutsaert, W.:A capillary correction for free surface flow of groundwater, Water Resour. Res., Vol.23, pp.805-808, 1987.

22) Pinder, G.F. and Gray, W. G.: Finite element simulation in surface and subsurface hydrology, Academic Press, London, p.295, 1977.

23) Scheidegger, A.E.: General theory of dispersion in porous media., J. Geophys. Res., Vol.66, pp.3273-3278, 1961.

24) Bear, J. : Dynamics of fluid in porous media, Dover, NY, pp.361-437, 1988.

25) 籾井和朗, 神野健二, 上田年比古, 伊藤敏朗, 細川土佐男, 平野文昭:不飽和領域を考慮した海岸自由地下水の塩水の侵 入・分散の数值解析, 日本地下水学会誌, Vol.28, No.3, pp.103-112, 1986.
26) Brooks, R.H. and Corey, A.T. : Properties of porous media affecting fluid flow, Proc. ASCE, IR, Vol.92, pp.61-88, 1966.

27) Irmay, S.: On the hydraulic conductivity of unsaturated soils, Trans. $A G U$, Vol.35, pp.463-467, 1954.

28) 谷 試:一次元鈆直不飽和浸透によって生じる水面上昇の特 性, 日本林学会誌, Vol.64, pp.409-418, 1982.

29) Vachaud, G. and Thony, J.L.:Hysteresis during infiltration and redistribution in a soil column at different initial water contents, Water Resour. Res., Vol.7, pp.111-127, 1971.

30) 内山雄介:潮位変動および密度の非一様性を考慮した砂浜海 岸地下水の非定常過程に関する数值解析, 港研報告, Vol.38, No.2, pp.3-27, 1999.

31) Loguet-Higgins, M.S.:Wave set-up, percolation and undertow in the surf zone, Proc. R. Soc. Lond., A 390, pp.283-291, 1983.

32) 片山 忠, 黒川 誠, 柳嶋慎一, 加藤一正, 長谷川䉷: 透水層 埋設による前浜地下水位の制御, 海岸工学論文集, 第 39 巻, pp.871-875, 1992.

\section{TIDAL CIRCULATION OF GROUNDWATER FLOW FORMED IN SANDY-BEACH AQUIFERS}

(2000.6.28 受付)

\section{Yusuke UCHIYAMA}

Numerical simulations are performed to examine the groundwater-flow fields in sandy-beaches. The model is based on Richards equation for saturated-unsaturated flow and advection-dispersion equation for salinity, incorporating tidal fluctuations into the seaward boundary conditions. The advantage of the present model is that it can accurately simulate unsteady behavior of groundwater in unconfined coastal aquifers considering the effects of water-level variations, density distributions and dynamics in the unsaturated zone. Computational results show that circulations are formed in the aquifer near the shoreline owing to the tidal oscillations, and accordingly saline seawater exists in this part. In addition, the structure of the circulation is greatly affected by amplitude of tidal fluctuations, density distribution, land-derived freshwater discharge, beach slope, and aquifer thickness. 